\title{
ANALISIS PENGARUH PERMINTAAN CABAI RAWIT (Capsicum Baccatum) DI DESA MOHUNGO KECAMATAN TILAMUTA
}

(Analysis that influence demand cayenne pepper (Capsicum Baccatum), in villages in Mohungo Kecamatan Tilamuta)

\author{
Andi Lelanovita Sardianti ${ }^{1^{*}}$ \\ ${ }^{1}$ Universitas Ichsan Gorontalo, Program Studi Agribisnis \\ Jl. Ahmad Najamuddin No.17 \\ Kota Gorontalo, Provinsi Gorontalo \\ *Email: andi.lelanovitasardianti@gmail.com
}

\begin{abstract}
ABSTRAK
Tujuan penelitian ini adalah mengetahui faktor-faktor yang berpengaruh terhadap permintaan cabai rawit (Capsicum Baccatum) di Desa Mohungo Kecamatan Tilamuta Kabupaten Boalemo. Metode yang digunakan dalam penelitian ini adalah metode wawancara dengan menggunakan daftar pertanyaan (kuesioner) sebagai alat bantu dalam mengumpulkan data dengan jumlah sampel yang digunakan adalah 20 sampel. Hasil penelitian disimpulkan bahwa beberapa Variabel seperti Permintaan cabai merah, permintaan Bawang Merah, Permintaan Tomat, Jumlah Pendapatan dan Jumlah tanggungan keluarga ternyata tidak memiliki pengaruh dengan jumlah permintaan cabai rawit pada Responden di Desa Mohungo Kecamatan Tilamuta Kabupaten Boalemo, sedangkan Variabel Permintaan Cabai merah keriting memiliki pengaruh terhadap Permintaan cabai rawit di Desa Mohungo Kecamatan Tilamuta Kabupaten Boalemo.
\end{abstract}

Kata Kunci: Pengaruh; permintaan; cabai rawit

\begin{abstract}
This research aimed to understand factors that influence demand cayenne pepper (Capsicum Baccatum), in villages in Mohungo Kecamatan Tilamuta Kabupaten Boalemo. Methods used in this research was a method of interviews using a list of questions (the questionnaire) as the tools in collecting the data with the total sample that is used was sample 20. The results of the study concluded that the place where several variables red chili as with a request, the request of onion, the request of tomatoes, the total revenues and the number of responsibility of other families that it turns out that have no influence with the number of requests among respondents in cayenne pepper village mohungo kecamatan tilamuta kabupaten boalemo. While variable demand curly red chili having influence to cayenne pepper in the village Mohungo Kecamatan Tilamuta Kabupaten Boalemo.
\end{abstract}

Keywords: The influence; demand; cayenne pepper

\section{PENDAHULUAN}

Sektor pertanian merupakan salah satu sektor di bidang ekonomi yang memiliki peran dan kedudukan penting dalam pembangunan nasional. Sektor pertanian ini berperan sebagai sumber penghasil bahan makanan, sumber bahan baku bagi industri, mata pencaharian sebagian besar penduduk, penghasil devisa negara dari ekspor komoditasnya bahkan 
berpengaruh besar terhadap stabilitas dan keamanan nasional. Sektor pertanian terbagi menjadi 5 yaitu tanaman pangan, hortikultura, peternakan, perikanan dan kehutanan (Maria, 2017). Komoditas hortikultura adalah salah satu komoditas potensial yang memiliki nilai ekonomi tinggi jika dikembangkan lebih lanjut. Produk hortikultura merupakan produk yang dibutuhkan secara berkelanjutan oleh masyarakat.

Salah satu tanaman hortikultura yang mempunyai nilai ekonomis tinggi dan komersial adalah tanaman cabai rawit (Capsicum Baccatum). Cabai rawit (Capsicum Baccatum) merupakan salah satu jenis sayuran komersial yang sejak lama telah dibudidayakan di Indonesia. Selain untuk memenuhi kebutuhan rumah tangga sehari-hari, cabai rawit (Capsicum Baccatum) banyak digunakan sebagai bahan baku industri pangan dan farmasi. Cabai mengandung protein, lemak, karbohidrat, kalsium $(\mathrm{Ca})$, fosfor $(\mathrm{P})$, besi $(\mathrm{Fe})$, vitamin-vitamin, dan mengandung senyawa-senyawa alkaloid, seperti capsaicin, flavenoid, dan minyak esensial. Dengan banyaknya manfaat dan kegunaan cabai rawit, dan semakin bertambahnya jumlah penduduk dan pendapatan maka permintaan terhadap cabai rawit (Capsicum Baccatum) juga akan semakin meningkat (Rukmana, 2008).
Beberapa penyebab penting komoditas cabai rawit (Capsicum Baccatum) perlu dikembangkan yaitu: (1) komoditi yang mempunyai nilai ekonomi tinggi (high economic value commodity), (2) komoditas unggulan nasional dan daerah, (3) menduduki posisi penting dalam menu pangan walaupun dalam jumlah kecil namun setiap hari dikonsumsi oleh banyak orang, (4) mempunyai manfaat yang cukup beragam dan sebagai bahan baku industry (Rukmana, 2008).

Kebutuhan cabai rawit terus meningkat dalam beberapa tahun terakhir seiring dengan bertambahnya kebutuhan masyarakat dan permintaan industri. Bahkan, pada waktu tertentu, khususnya menjelang hari raya dan hari besar keagamaan, kebutuhan cabai meningkat melampaui ketersediaannya di pasaran. Akibatnya, harga cabai melambung tinggi. Sejalan dengan peningkatan jumlah penduduk dan perkembangan industry pengolahan yang berbahan baku cabai rawit (Capsicum Baccatum), maka diperkirakan laju permintaan komoditas cabai rawit (Capsicum Baccatum) akan terus mengalami peningkatan dan apabila peningkatan permintaan tidak diikuti dengan peningkatan produksi atau pasokan bahan baku cabai rawit maka dapat menyebabkan tidak terpenuhinya permintaan masyarakat salah satu sebab tidak terpenuhinya permintaan karena 
produsen/petani kurang pemahaman tentang sebab atau alas an sebab konsumen melakukan permintaan cabai rawit. Permintaan akan cabai rawit (Caspicum Baccatum) memiliki pengaruh dengan banyak hal, seperti harga cabai rawit itu sendiri, dan harga barang lain yang dapat menjadi barang subtitusi atau komplementer, jumlah penduduk serta pendapatan konsumen. Bila hal-hal tersebut dapat diketahui dengan jelas, maka akan dapat dilakukan langkah-langkah yang lebih baik dalam usaha memenuhi kebutuhan dan permintaan masyarakat terhadap cabai rawit (Capsicum Baccatum).

Kabupaten Boalemo merupakan salah satu sentra pengembangan cabai di Provinsi Gorontalo yang mencapai produksi $35,81 \%$ terhadap produksi cabai (BPS, 2017). Kontribusi tersebut menempatkan Boalemo sebagai penghasil cabai ketiga terbanyak setelah Bone Bolango dan Gorontalo. Masyarakat Provinsi Gorontalo, terutama di Kabupaten Boalemo, sangat lekat dengan cabai sebagai bumbu masakan, selain menjadi pendamping utama makanan pokok. Namun, peningkatan produksi tersebut kerap kali diiringi dengan permintaan berfluktuatif dari konsumen sehingga terjadi resiko penurunan harga.

Berdasarkan hal yang telah dikemukakan tersebut diatas, maka akan dilaksanakan suatu penelitian dengan judul "Faktor-faktor yang mempengaruhi
Permintaan Cabai Rawit (Capsicum Baccatum) di Desa Mohungo Kecamatan Tilamuta Kabupaten Boalemo". adapun Tujuan dalam penelitian ini adalah untuk mengetahui faktor-faktor yang berengaruh terhadap permintaan cabai rawit di Desa Mohungo Kecamatan Tilamuta, Kabupaten Boalemo.

\section{METODE PENELITIAN}

Metode pengumpulan data yang digunakan dalam penelitian ini adalah Data Primer dan data sekunder. Data primer dalam penelitian ini adalah data yang diperoleh secara langsung dari hasil wawancara terstruktur dengan petani responden cabai rawit (Capsicum Baccatum) dengan bantuan kuisioner sedangkan Data sekunder dalam penelitian ini yaitu, data yang didapatkan dari instansi terkait antara lain Kantor Desa Mohungo serta BPS Kabupaten Boalemo di Kecamatan Tilamuta.

Teknik yang digunakan pada sampel penelitian ini adalah teknik non probability sampling dengan teknik purposive sampling. Menurut Sugiyono (2005) purposive sampling adalah "Teknik penentuan sampel dengan pertimbangan tertentu".

Pertimbangan yang digunakan dalam penelitian ini adalah sebagai berikut:

a. Konsumen yang telah melakukan pembelian Cabai Rawit.

b. Konsumen yang berdomisili di Kecamatan Tilamuta. 
c. Konsumen yang berumur 17 tahun keatas.

Dalam penelitian ini jumlah sampel yang digunakan adalah 20 sampel.

Analisis data yang digunakan adalah analisis regresi dengan rumus :

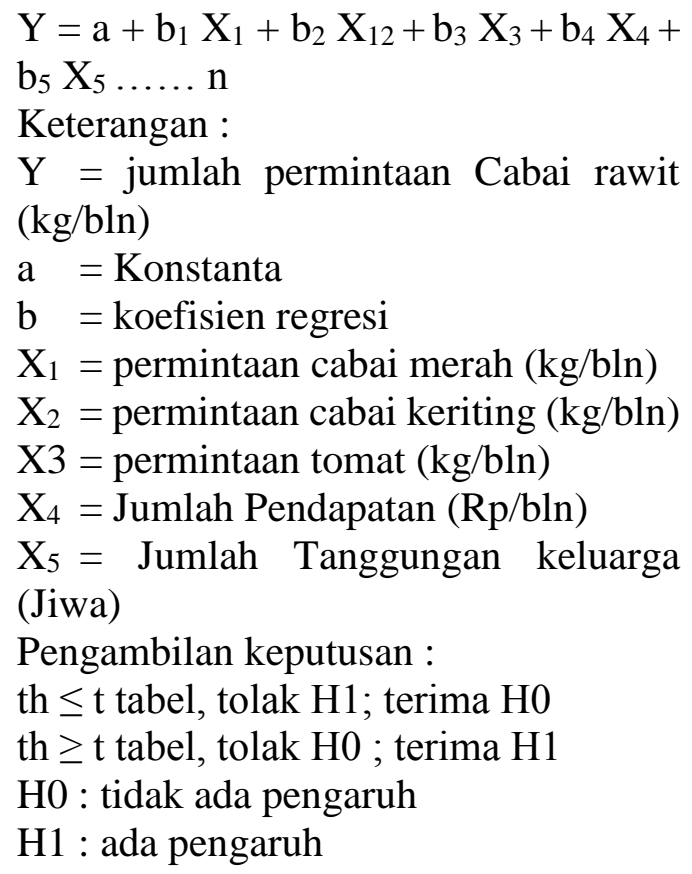

\section{HASIL DAN PEMBAHASAN}

\section{Faktor-Faktor yang Berpengaruh Terhadap Permintaan Cabai Rawit}

Analisis yang berpengaruh terhadap permintaan cabai rawit di Desa Mohungo Kecamatan Tilamuta Kabupaten Boalemo untuk penelitian ini hanya dibatasi pada permintaan cabai merah, permintaan cabai merah keriting, tomat, bawang merah, Jumlah pendapatan, dan Jumlah Anggota Keluarga.

\section{a. Cabai merah}

Permintaan cabai merah dalam penelitian ini adalah jumlah uang yang dibayarkan oleh Responden untuk mendapatkan satu kilogram cabai merah. Data mengenai permintaan cabai merah dapat dilihat pada tabel 1 berikut :

Tabel 1. Hasil analisis pengaruh permintaan cabai rawit terhadap cabai merah

\begin{tabular}{cccccrr}
\hline \multirow{2}{*}{ Model } & \multicolumn{2}{c}{ Unstandardized Coefficients } & \multicolumn{2}{c}{$\begin{array}{c}\text { Standardized } \\
\text { Coefficients }\end{array}$} & t & Sig. \\
\cline { 2 - 4 } & $\mathrm{B}$ & Std. Error & Beta & & \\
\hline (Constant) & 4.058 & .224 & & 18.112 & .000 \\
cabai_merah & .047 & .221 & .049 & .210 & .836 \\
\hline
\end{tabular}

\section{Berdasarkan Nilai Signifikansi (Sig.)}

Berdasarkan tabel output SPSS "coefficients" di atas diketahui nilai signifikansi (Sig) variabel permintaan cabai merah (X1) adalah sebesar 0,836. karena nilai Sig. $0.836>0,05$, maka dapat disimpulkan bahwa permintaan cabai merah tidak ada pengaruh terhadap permintaan cabai rawit.

\section{a) Perbandingan Nilai $t$ hitung dengan $t$ tabel (uji t pertama)}

Berdasarkan output tersebut diketahui nilai $\mathrm{t}$ hitung variabel permintaan cabai merah adalah sebesar 0,210. karena nilai t hitung $0,210<\mathrm{t}$ tabel 1,734, maka dapat disimpulkan bahwa tidak ada pengaruh permintaan cabai merah terhadap permintaan cabai rawit.

Berdasarkan dari data tersebut dapat dijelaskan bahwa cabai merah tidak berpengaruh dengan permintaan cabai rawit hal ini disebabkan karena konsumen 
menganggap bahwa cabai merah tidak memiliki kontribusi yang berarti bagi olahan masakan penduduk yang ada didaerah penelitian berdasarkan dengan permintaan konsumsi cabai rawit mereka. Umumnya konsumen mengkonsumsi cabai rawit tanpa perlu adanya tambahan dari produk cabai merah.

\section{b. Cabai Merah Keriting}

Permintaan cabai merah keriting dalam penelitian ini adalah jumlah uang yang dibayarkan oleh penduduk untuk mendapatkan satu kilogram cabai merah keriting. Data mengenai permintaan cabai merah keriting dapat dilihat pada tabel 2 berikut :

Tabel 2. Hasil analisis pengaruh permintaan cabai rawit terhadap cabai keriting

\begin{tabular}{|c|c|c|c|c|c|}
\hline \multirow[t]{2}{*}{ Model } & \multicolumn{2}{|c|}{ Unstandardized Coefficients } & $\begin{array}{c}\text { Standardized } \\
\text { Coefficients }\end{array}$ & \multirow[t]{2}{*}{$\mathrm{t}$} & \multirow[t]{2}{*}{ Sig. } \\
\hline & B & Std. Error & Beta & & \\
\hline (Constant) & 3.406 & .312 & & 10.931 & .000 \\
\hline cabai_keriting & .566 & .244 & .481 & 2.325 & .032 \\
\hline
\end{tabular}

\section{a). Berdasarkan Nilai Signifikansi (Sig.)}

Berdasarkan tabel output SPSS "coefficients" di atas diketahui nilai signifikansi (Sig) variabel permintaan cabai keriting (X2) adalah sebesar 0,032. karena nilai Sig. $0.032<0,05$, maka dapat disimpulkan bahwa permintaan cabai keriting berpengaruh terhadap permintaan cabai rawit.

\section{b). perbandingan Nilai $t$ hitung dengan $t$ tabel (uji t pertama)}

Berdasarkan output tersebut

diketahui nilai t hitung variabel permintaan cabai keriting adalah sebesar 2.325 karena nilai t hitung 2,325 > t tabel 1,734, maka dapat disimpulkan bahwa ada pengaruh permintaan cabai keriting terhadap permintaan cabai rawit.

Berdasarkan dari data tersebut dapat dijelaskan bahwa cabai merah keriting memiliki pengaruh dengan permintaan cabai rawit hal ini disebabkan karena konsumen menganggap bahwa cabai merah keriting umumnya digunakan bagi konsumen untuk penambahan pada olahan masakan agar dapat memberikan sensasi yang lebih pedas dan memiliki aroma serta warna yang khas sehingga konsumen menganggap bahwa cabai merah keriting memiliki kontribusi yang berarti bagi olahan masakan mereka.

\section{c. Bawang Merah}

Permintaan bawang merah dalam penelitian ini adalah jumlah uang yang dibayarkan oleh penduduk untuk mendapatkan satu liter bawang merah. Data mengenai permintaan bawang merah dapat dilihat pada tabel 3 berikut : 
Tabel 3. Hasil analisis pengaruh permintaan cabai rawit terhadap bawang merah

\begin{tabular}{|c|c|c|c|c|c|}
\hline \multirow[t]{2}{*}{ Model } & \multicolumn{2}{|c|}{ Unstandardized Coefficients } & \multirow{2}{*}{$\begin{array}{c}\text { Standardized } \\
\text { Coefficients }\end{array}$} & \multirow[t]{2}{*}{$\mathrm{t}$} & \multirow[t]{2}{*}{ Sig. } \\
\hline & B & Std. Error & & & \\
\hline (Constant) & 4.245 & .384 & & 11.065 & .000 \\
\hline bawang_merah & -.032 & .082 & -.092 & -.393 & 699 \\
\hline
\end{tabular}

a). Berdasarkan nilai signifikansi (Sig.)

Berdasarkan tabel output SPSS "coefficients" di atas diketahui nilai signifikansi (Sig) variabel permintaan bawang merah (X3) adalah sebesar 0,699. karena nilai Sig. $0.699>0,05$, maka dapat disimpulkan bahwa permintaan bawang merah tidak ada pengaruh terhadap permintaan cabai rawit.

\section{b). Perbandingan Nilai $t$ hitung dengan $t$ tabel (uji t pertama)}

Berdasarkan output SPSS di atas diketahui nilai t hitung variabel permintaan bawang merah adalah sebesar 0,-393 karena nilai t hitung $0,-393<\mathrm{t}$ tabel 1,734, maka dapat disimpulkan bahwa tidak ada pengaruh permintaan bawang merah terhadap permintaan cabai rawit.
Berdasarkan dari data tersebut dapat dijelaskan bahwa bawang merah tidak ada pengaruh dengan permintaan cabai rawit hal ini disebabkan karena konsumen menganggap bahwa bawang merah dalam olahan masakan cabai rawit hanya sebagai penyedap rasa saja bahkan kerapkali olahan tersebut tidak menggunakan bawang merah sehingga dianggap tidak memiliki kontribusi yang sangat berarti bagi olahan masakan cabai rawit.

\section{d. Tomat}

Permintaan tomat dalam penelitian ini adalah jumlah uang yang dibayarkan oleh penduduk untuk mendapatkan satu kilogram tomat. Data mengenai permintaan tomat dapat dilihat pada tabel 4 berikut :

Tabel 4. Hasil analisis pengaruh permintaan cabai rawit terhadap tomat

\begin{tabular}{|c|c|c|c|c|c|}
\hline \multirow{2}{*}{ Model } & \multicolumn{2}{|c|}{ Unstandardized Coefficients } & \multirow{2}{*}{$\begin{array}{c}\text { Standardized } \\
\text { Coefficients } \\
\text { Beta }\end{array}$} & \multirow{2}{*}{$\mathrm{t}$} & \multirow{2}{*}{ Sig. } \\
\hline & $\mathrm{B}$ & Std. Error & & & \\
\hline (Constant) & 3.889 & .657 & & 5.921 & .000 \\
\hline Tomat & .056 & .171 & .076 & .325 & .749 \\
\hline
\end{tabular}

a). Berdasarkan nilai signifikansi (Sig.)

Berdasarkan tabel output SPSS "coefficients" di atas diketahui nilai signifikansi (Sig) variabel permintaan tomat
(X4) adalah sebesar 0,749. karena nilai Sig. $0.749>0,05$, maka dapat disimpulkan bahwa permintaan tomat tidak berpengaruh terhadap permintaan cabai rawit. 


\section{b). Perbandingan Nilai $t$ hitung dengan $t$ tabel (uji t pertama)}

Berdasarkan output SPSS di atas diketahui nilai t hitung variabel permintaan tomat adalah sebesar 0.325 karena nilai $\mathrm{t}$ hitung $0,325<\mathrm{t}$ tabel 1,734, maka dapat disimpulkan bahwa tidak ada pengaruh permintaan tomat terhadap permintaan cabai rawit.

Berdasarkan dari data tersebut dapat dijelaskan bahwa tomat tidak b dengan permintaan cabai rawit hal ini disebabkan karena umumnya konsumen mengkonsumsi cabai rawit tanpa perlu melakukan penambahan tomat dalam setiap konsumsinya karena tomat di daerah penelitian kerapkali hanya digunakan sebagai bahan tambahan buah dan sayur pada makanan tertentu saja.

\section{e. Jumlah Pendapatan}

Pendapatan dalam penelitian ini adalah jumlah uang yang didapatkan oleh Responden untuk mendapatkan atau membeli satu kilogram cabai rawit. Data mengenai permintaan cabai rawit dapat dilihat pada tabel 5 berikut :

Tabel 5. Hasil analisis pengaruh permintaan cabai rawit terhadap cabai merah

\begin{tabular}{lrrrrr}
\hline \multirow{2}{*}{ Model } & \multicolumn{2}{c}{ Unstandardized Coefficients } & \multicolumn{2}{c}{$\begin{array}{c}\text { Standardized } \\
\text { Coefficients }\end{array}$} & \multirow{2}{*}{ Sig. } \\
\cline { 2 - 5 } & \multicolumn{1}{c}{ B } & Std. Error & Beta & & \\
\hline (Constant) & 3.586 & .358 & & 10.017 & .000 \\
jumlah_pendapatan & $1.605 \mathrm{E}-7$ & .000 & .331 & 1.490 & .154 \\
\hline
\end{tabular}

\section{a). berdasarkan nilai signifikansi (Sig.)}

Berdasarkan tabel output SPSS "coefficients" di atas diketahui nilai signifikansi (Sig) variabel jumlah pendapatan (X5) adalah sebesar 0,154. karena nilai Sig. $0.154>0,05$, maka dapat disimpulkan bahwa jumlah pendapatan tidak berpengaruh terhadap permintaan cabai rawit.

\section{b). perbandingan Nilai $t$ hitung dengan $t$ tabel (uji t pertama)}

Berdasarkan output SPSS di atas diketahui nilai $\mathrm{t}$ hitung variabel jumlah pendapatan adalah sebesar 1.490 karena nilai t hitung $1,490<\mathrm{t}$ tabel 1,734 , maka dapat disimpulkan bahwa tidak ada pengaruh jumlah pendapatan terhadap permintaan cabai rawit.

Berdasarkan dari data tersebut dapat dijelaskan bahwa pendapatan tidak berpengaruh dengan permintaan cabai rawit hal ini disebabkan karena tinggi rendahnya pendapatan rumah tangga tidak memiliki pengaruh dengan permintaan cabai rawit karena di daerah penelitian cabai rawit merupakan salah satu menu wajib dalam konsumsi masyarakat sehingga konsumen menganggap bahwa tingginya pendapatan 
tidak mempengaruhi mereka dalam keluarga yang ikut serta secara bersamamengkonsumsi cabai rawit.

\section{f. Jumlah Anggota Keluarga} sama dibayarkan. Data mengenai Jumlah tanggungan keluarga dapat dilihat pada tabel berikut:

Jumlah tanggungan keluarga dalam penelitian ini adalah jumlah anggota Tabel 6. Hasil analisis pengaruh permintaan cabai rawit terhadap cabai merah

\begin{tabular}{|c|c|c|c|c|c|}
\hline \multirow{2}{*}{ Model } & \multicolumn{2}{|c|}{ Unstandardized Coefficients } & \multirow{2}{*}{$\begin{array}{c}\begin{array}{c}\text { Standardized } \\
\text { Coefficients }\end{array} \\
\text { Beta }\end{array}$} & \multirow[t]{2}{*}{$\mathrm{t}$} & \multirow{2}{*}{ Sig. } \\
\hline & $\mathrm{B}$ & Std. Error & & & \\
\hline (Constant) & 3.654 & .366 & & 9.993 & .000 \\
\hline $\begin{array}{c}\text { Jumlah anggota } \\
\text { keluarga }\end{array}$ & .100 & .079 & .286 & 1.266 & .222 \\
\hline
\end{tabular}

a). berdasarkan nilai signifikansi (Sig.) Berdasarkan tabel output SPSS "coefficients" di atas diketahui nilai signifikansi (Sig) variabel jumlah anggota keluarga (X2) adalah sebesar 0,222. karena nilai Sig. $0.222>0,05$, maka dapat disimpulkan bahwa jumlah anggota keluarga tidak berpengaruh terhadap permintaan cabai rawit.

\section{b). Perbandingan Nilai $t$ hitung dengan $t$ tabel (uji t pertama)} berdasarkan output SPSS di atas diketahui nilai $\mathrm{t}$ hitung variabel jumlah anggota keluarga adalah sebesar 1.266 karena nilai $\mathrm{t}$ hitung 1,266 > t tabel 1,734, maka dapat disimpulkan bahwa tidak ada pengaruh jumlah anggota keluarga terhadap permintaan cabai rawit.

Berdasarkan dari data tersebut dapat dijelaskan bahwa jumlah anggota keluarga tidak berpengaruh dengan permintaan cabai rawit hal ini disebabkan karena jumlah anggota keluarga pada responden penelitian rata-rata 3 hingga 5 orang sehingga nilai konsumsinya berada pada tahap homogen.

\section{KESIMPULAN}

Berdasarkan hasil penelitian di Desa Mohungo Kecamatan Tilamuta Kabupaten Boalemo maka dapat disimpulkan bahwa : beberapa Variabel seperti Permintaan cabai merah, permintaan Bawang Merah, Permintaan Tomat, Jumlah Pendapatan dan Jumlah tanggungan keluarga ternyata tidak memiliki pengaruh dengan jumlah permintaan cabai rawit pada Responden di Desa Mohungo Kecamatan Tilamuta Kabupaten Boalemo, sedangkan Variabel Permintaan Cabai merah keriting memiliki pengaruh terhadap Permintaan cabai rawit di Desa Mohungo Kecamatan Tilamuta Kabupaten Boalemo 


\section{DAFTAR PUSTAKA}

Badan Pusat Statistik. 2017. Data Konsumsi Cabai Rawit Kecamatan Tilamuta Kabupaten Boalemo. Gorontalo.

Kantor Desa Mohungo. 2018. Profil Desa Mohungo Kecamatan Tilamuta Kabupaten Boalemo. Gorontalo.

Maria. 2017. Peranan sektor pertanian, kehutanan dan perikanan. PPS Unila Bandar Lampung

Rukmana, R. 2008. Cabai Hibrida Sistem Mulsa Plastik. Kanisius.

Yogyakarta. 